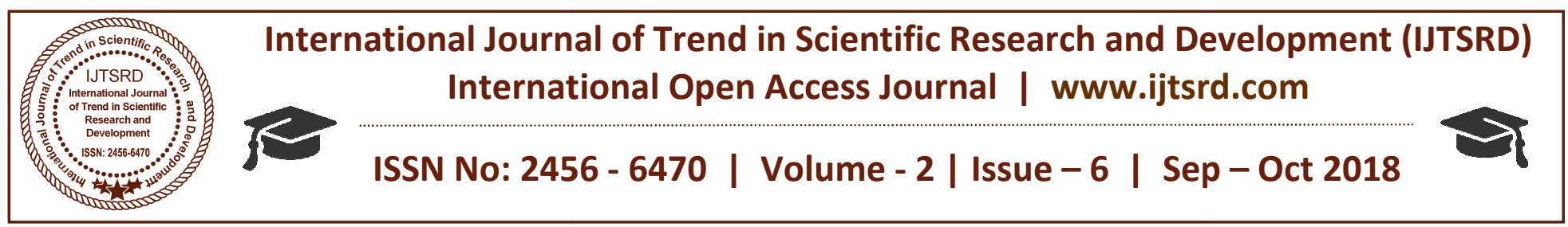

\title{
Assessment of some Chemical Properties of Isan - Ekiti Soil, Southwestern Nigeria
}

\author{
Silas A. Oladapo, Adeyemi E. Adetoro \\ Lecturers, Department of Civil Engineering, Federal Polytechnic, Nigeria, Africa
}

\begin{abstract}
Increase in knowledge of Chemical properties of soil will prevent or reduce road failure in tropical climate such as Nigeria. This study aimed at assessing some chemical properties of lateritic soil deposited in Isan Ekiti, South-western Nigeria. Soil samples collected from the study area were subjected to CEC, Organic Carbon content, $\mathrm{pH}$ and Refractive Index tests. The CEC, Organic Carbon content, $\mathrm{pH}$ and Refractive Indices values for all the soil samples varied from 35.00 to $58.00 \%, 31.00$ to $46.00 \%, 6.00$ to $6.21 \%$ and 1.529 to $1.533 \%$ respectively. It could be generally observed there were presence of large deposit of lateritic soil with large contents of clay and its minerals. The soil in the study area were acidic in nature (though weak) and likely to have high retention capacity. There could be presence of clay minerals such as Allophone, Chlorite, Illite and Steatite in study area's soil. Further study on the other Engineering properties of the soil should be carried out.
\end{abstract}

Keywords: Clay minerals, Engineering properties, pH, Organic Carbon content, Soil.

\section{INTRODUCTION}

Assessment of soil engineering properties will bring about increase in the knowledge of what the soil is made up of. It reduces the environmental impacts due to soil amendments and increases the efficiency of resource inputs. It gives room to Engineering application for total solution to soil problems. Thus, it must not be taken with kid's gloves. There will be need to assess its chemical properties which would help in knowing its retention capacity, acidity, alkalinity, hydrogen index among others. These properties among others would foster firm decision in determination of soil usage in Civil Engineering projects e.g. road filling.
In tropical and sub-tropical climates countries such as Nigeria, lateritic soils are required or used in different Engineering works especially for filling. As earlier stated, the need to assess chemical properties of this lateritic soil-will help in knowing the type of clay minerals that are present in it, its acidity or alkalinity, retention capacity, $\mathrm{pH}$ among others especially in the study area. There are some cases where a lateritic soil may contain large quantity of clay minerals, which will reduce its strength and durability under load especially in moisture's presence [3].

From time immemorial, lateritic soils are successfully used as fills for road construction in Nigeria, but there are usual failures of road pavements since independence [4]. Thus, there is need for thorough assessment of Nigeria lateritic soils engineering properties especially chemical ones. This will also help in knowing the stabilization technique to be used for its improvement if need be.

According to [4], many authors have worked on distribution, classification, depth extent, general nature, formation and geotechnical assessment of late rites in Nigeria; but little or no attention has been paid to the chemical properties of the study area's late rites. The research work sought to assess some chemical properties of Isan Ekiti soil in southwestern part of Nigeria, Ekiti State precisely. There is large deposit of lateritic soil in the study area. The chemical properties put into consideration were Cation Exchange Capacity (CEC), Organic Carbon content, $\mathrm{pH}$ and Refractive Index. These properties will help in determining the clay minerals, retention capacity, acidity or alkalinity of the lateritic soil deposit; which will also serve as data source for Civil Engineers. 


\section{A. Study Area}

The study area is Isan-Ekiti, Oye Local Government Area (LGA), Ekiti State - a state in western Nigeria declared as a state on 1st October, 1996 alongside five others by the military under the dictatorship of General Sani Abacha. The state, carved out of the territory of old Ondo State, covers the former twelve local government areas that made up the Ekiti Zone of old Ondo State. On creation, it had sixteen Local Government Areas (LGAs), having had an additional four carved out of the old ones. One of these sixteen LGAs is Oye LGA, which is surrounded by Kwara State in the North, Ikole LGA in the East, Ileje-Meje / Ido-Osi LGAs in the West and Irepodun / Ifelodun LGA in the South as shown in Fig. 1 [8].

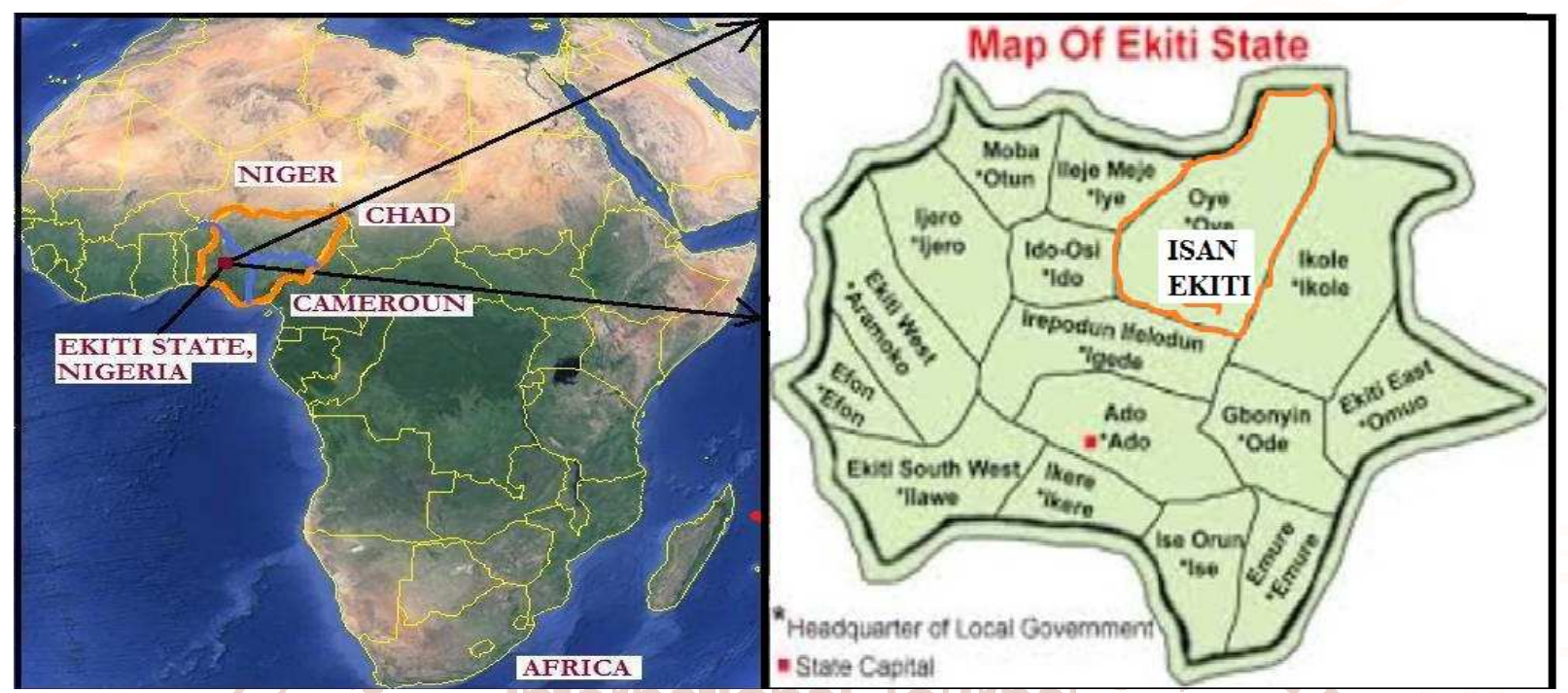

Figure 1: Location of the Study Area- Isan-Ekiti, Ekiti State (Source: [9])

Isan - Ekiti is located on Latitude $7^{0} 55^{\prime} \mathrm{N}$ and Longitude $5^{0} 19^{\prime} \mathrm{E}$. Geologically, its landscape consists of ancient plains broken by steep sided outcropping dome rocks situated within tropical climate of Nigeria and underlain by metamorphic rocks of the Precambrian basement complex of Southwestern Nigeria, which are very ancient in age as shown in fig. 2. These basement complex rocks showed great variations in grain size and in mineral composition. The rocks are quartz gneisses and schist's consisting essentially of quartz with small amounts of white mizageous minerals. In grain size and structure, the rocks vary from very coarse-grained pegmatite to medium-grained gneisses. The rocks are strongly foliated and occur as outcrops. The soils derived from the basement complex rock are mostly well drained, having medium to coarse in texture. The geological nature of the study area and its increased urbanization make it more vulnerable and of public health concern when it comes to water quality ([1], [8]).

The Study area is within the tropical climate of Southwestern Nigeria with two distinct seasons namely rainy season (April-October) and dry season (November-March). Its Temperature is between $21^{\circ}$ and $28^{\circ} \mathrm{C}$ with high humidity. The south westerly wind and the northeast trade winds blow in the rainy and dry (Harmattan) seasons respectively [8].

\section{B. Cation Exchange Capacity (CEC)}

CEC of a soil is its ability to exchange cations between the soil particles and the water in the soil. This depends upon the negative electric charge on the surface of soil particles, thus attracts the cations, disallowing them from leaching away. CEC is used as a measure of fertility, retention capacity, and shows a soil's ability to protect groundwater from contamination. It also shows soil's structural shrinkswell potential: a low value $(<20 \mathrm{Cmol} / \mathrm{kg})$ shows that a soil will not recover from compaction, while a high value $(>40 \mathrm{Cmol} / \mathrm{k} \mathrm{g})$ shows that soil structure will recover naturally. Organic matter and most clays (except kaolinite) have high CEC, while sands have almost no CEC. Thus, clays and organic matter retain nutrients than sandy soils, which have ability to lose them quickly. A meaningful CEC for a sandy soil is likely to be $5 \mathrm{Cmol} / \mathrm{kg}, 30 \mathrm{Cmol} / \mathrm{kg}$ for clay loam. While humus has a typical value of $250 \mathrm{Cmol} / \mathrm{kg}$ [2] .

\section{Power of Hydrogen (pH)}

This is the measure of the acidity or alkalinity of soil and groundwater. The quantity of negative charge 
from deprotonation of clay hydroxy groups or organic matter is governed by the $\mathrm{pH}$ of the surrounding solution. Increase in the $\mathrm{pH}$ (i.e. decreasing the $\mathrm{H}^{+}$ cations' concentration) increases this variable charge, thus increases the CEC. Soil's parent materials and its development conditions govern CEC. These parameters are also significant for soil $\mathrm{pH}$ determination [2].

\section{Organic Carbon content Test}

The quantity of organic carbon in soil is governed by soil texture, climate, vegetation, historical and current land use management. Effects of soil texture on organic carbon content can be due to the stabilizing effects of clay on organic matter, which can be trapped into the minutes' spaces between clay particles making them inaccessible to microorganisms, thus slowing decomposition. Moreover, clay gives chemical protection to organic matter through adsorption onto clay surfaces, which also prevents organic matter from being decomposed by bacteria. Thus, soil with high clay content have possibility of higher organic carbon content than soils with low clay content under similar land use and climate conditions [5]. Soil organic matter contains 5 $\%, 0.5 \%$ and $0.5 \%$ of Nitrogen, Phosphorus and Sulphur. Thus having the ratio of $10: 1: 1$. This is determined by the quantity of Carbon present, as this element represents $52-58 \%$ of the organic matter [6].

\section{MATERIALS AND METHODS}

Soil samples were collected from four pits dug within the study area (Namely Sample A, B, C and D) at depth between $1.00 \mathrm{~m}$ and $2.00 \mathrm{~m}$ after topsoil removal using method of disturbed sampling. The soil samples collected were stored in polythene bag to maintain its natural moisture contents. The samples were then taken to the Chemistry laboratory of Science and Technology Department, the Federal Polytechnic, Ado-Ekiti, Nigeria where the chemical analyses were carried out.

The tests carried out on the samples were CEC, $\mathrm{pH}$, Organic Carbon Content and Refractive Index tests. The CEC was measured using atomic absorption spectrophotometer machine AAS machine (PG 990 Model). The soil organic carbon content was determined using Walkley-Black chromic acid wet oxidation method. The $\mathrm{pH}$ was measured using Hanna Instrument (HI 98129 model), while the soils refractive indices were carried out using Laser diffraction (Malvern Mastersizer 3000). The results were then analysed. All the tests were conducted in accordance with [7].

\section{RESULTS AND DISCUSSION}

Table 1 showed colours and organic carbon contents of the soil samples. The colours of the soils samples were acquired on the field through visual inspection / assessment. Field observation also showed that the soil constituents comprises of clay, sand and gravel. It is observed that the organic carbon content of the soil from the study area ranges between 31 and $46 \%$. Thus, the average soil from the study area has a bit high carbon content. This portrays presence of large content of clay [5].

\begin{tabular}{|c|c|c|}
\hline $\begin{array}{l}\text { SAMPLE } \\
\text { CODE }\end{array}$ & COLOUR & $\begin{array}{c}\text { ORGANIC } \\
\text { CARBON } \\
\text { CONTENT }(\%)\end{array}$ \\
\hline A & Yellowish & 44.1 \\
\hline $\mathrm{B}$ & Brownish & 41.0 \\
\hline $\mathrm{C}$ & Reddish & 31.0 \\
\hline $\mathrm{D}$ & $\begin{array}{l}\text { Brownish } \\
\text { Red }\end{array}$ & 46.0 \\
\hline
\end{tabular}

Table 2 showed CEC, $\mathrm{pH}$ and Refractive Indices tests results for the soil samples. It is observed that the CEC, $\mathrm{pH}$ and Refractive Indices values varied from 35.00 to $58.00 \%, 6.00$ to $6.21 \%$ and 1.529 to $1.533 \%$ respectively for all the soil samples.

Table 2: Some Chemical Properties of the Soil Samples

\begin{tabular}{|c|c|c|c|}
\hline $\begin{array}{c}\text { SAMPL } \\
\text { E CODE }\end{array}$ & pH & $\begin{array}{c}\text { CEC } \\
(\mathrm{Cmol} / \mathrm{kg})\end{array}$ & $\begin{array}{c}\text { REFRA CTIV } \\
\text { E INDEX }\end{array}$ \\
\hline $\mathrm{A}$ & 6.00 & 54.00 & 1.533 \\
\hline $\mathrm{B}$ & 6.01 & 34.00 & 1.532 \\
\hline $\mathrm{C}$ & 6.15 & 58.00 & 1.529 \\
\hline $\mathrm{D}$ & 6.21 & 35.00 & 1.530 \\
\hline
\end{tabular}

According to [2], all the soil samples have high contents of clay and its minerals due to their little bit high CEC and Refractive Index (RI) values (for clay, $\mathrm{CEC}>30 \mathrm{Cmol} / \mathrm{kg}$, RI between 1.47 and 1.68). Soil samples B and D were likely to have presence of Illite and Chlorite $(10$ - $40 \mathrm{Cmol} / \mathrm{kg}$ ) clay minerals. Soil samples $\mathrm{A}$ and $\mathrm{D}$ were likely to have presence of Halloysite $(40$ - $60 \mathrm{Cmol} / \mathrm{kg}$ ) clay mineral. While all the soil samples were also likely to have presence of Allophone $(30-135 \mathrm{Cmol} / \mathrm{kg})$ and Smectite $(25-$ $100 \mathrm{Cmol} / \mathrm{kg}$ ) clay minerals. Soil samples A and C 
$(>40 \mathrm{Cmol} / \mathrm{kg}$ ) also showed that their soil structure would recover naturally from compaction.

Generally, all the soil samples (i.e. pH between 6.00 and 6.21) have weak acidity nature and in descending order of $\mathrm{D}>\mathrm{C}>\mathrm{B}>\mathrm{A}$. The retention capacities of the soil were in descending order of $\mathrm{C}>\mathrm{A}>\mathrm{D}>\mathrm{B}$ as the higher the CEC value, the higher the retention capacity.

\section{CONCLUSION}

There were presence of large deposit of lateritic soil with large contents of clay and its minerals. The soil in the study area were acidic in nature, though weak. The soil were likely to have high retention capacity. There could be presence of clay minerals such as Allophone, Chlorite, Illite and Smectite in study area's soil. Further study on the other Engineering properties of the soil should be carried out.

\section{REFERENCES}

1. Adetoro, A. E. and Abe, O. E. (2018). Assessment of Engineering Properties of AdoEkiti to Ikere-Ekiti Road Soil, Southwestern Nigeria. WWJMRD, 4(6), pg. 191- 195.

2. Brady, N. C. and Weil, R. R. (2008). The Nature and Properties of Soils (14th ed.). USA, Pearson: Upper Saddle River.

3. Dada, M. O. and Olulope, O. R. (2018). Potentials of Palm Kernel Ash as Partial Replacement of Lime on the Geotechnical Properties of Lateritic
Soil for Road Construction. WWJMRD, 4 (6), pg. 199 - 202.

4. Otoko, G. R. \& Honest, B. K. (2014). Stabilization of Nigerian Deltaic Laterites with Saw Dust Ash. International Journal of Scientific Research and Management. Vol. 2(8). Pg. 1287 1292.

5. Dada, M. O. and Adam, J. O. (2018). Effects of Organic Carbon Content and Water Stable Aggregate on the Development of Rill and Gully Erosion in Aramoko -Ekiti. International Journal of Trend in Scientific Research and Development (IJTSRD), 2(5), pg. 721 - 724.

6. Vlab.amrita.edu, (2013). Soil AnalysisDetermination of Available Organic Carbon content in the Soil. Retrieved 16 September 2018, from

vlab. amrita.edu/ sub $=2 \&$ brch $=294 \& \operatorname{sim}=1552 \& \mathrm{c}$

7. British Standard 1377 - BS 1377 (1990). British Standard Methods of Test for Soils for Civil Engineering Purposes. UK, London: British Standards Institution.

8. Ekiti State Directorate of ICT (2018). The Official Website of the Government of Ekiti State, Nigeria.

Available: https://ekitistate.gov.ng/administration/local-govt/.

9. Google (2018). Google Earth 2015. USA, US Navy: US Department of Geographer. Available: http://earth.google.com/. 